\title{
PENENTUAN JUMLAH PEMBELIAN BAHAN BAKU BERDASARKAN METODE ECONOMIC ORDER QUANTITY PADA PT. DAYA SAKTI INDUSTRI MAKASSAR
}

\section{ABDUL RAHMAN \\ DOSEN STIE WIRA BHAKTI MAKASSAR abd.rahman@gmail.com}

\begin{abstract}
Abstrak
Penelitian ini bertujuan 1) Untuk mengetahui besarnya pembelian persediaan bahan baku berdasarkan Economic Order Quantity. 2) Untuk mengetahui pada saat kapan perusahaan harus melakukan pemesanan kembali dengan jumlah pemesanan bahan baku yang tepat dengan biaya yang relatif kecil.Sedangkan jenis penelitian Kuantitatif, dengan menggunakan metode analisis data 1) Metode Kuantitas Pesanan Ekonomis (Economical Order Quantity) 2) Metode Titik Pemesanan Kembali (Reorder Point), 3) Persediaan pengaman (safett stock).Hasil penelitian menunjukkan bahwa diketahui banyaknya persediaan dengan menggunakan bahwa metode Economic Order Quantity (EOQ) adalah 102.469,507 dibulatkan menjadi 102.469 unit. Dari hasil perhitungan diperoleh hasil total biaya persediaan bahan baku sebesar Rp. 154.144.750.

Kata kunci : Bahan Baku, Economic Order Quantity, Reorder Point, Safety Stock
\end{abstract}

\section{PENDAHULUAN}

Barang persediaan (inventory) adalah barang-barang yang biasanya dapat dijumpai digudang tertutup, lapangan, gudang terbuka atau tempat-tempat penyimpanan lain. Tidak peduli apakah perusahaan besar atau kecil, untuk pengadaan dan penyimpanan barang ini diperlukan biaya besar. Biasanya biaya paling besar adalah nilai persediaan dan biaya penyimpanannya. Persediaan bahan baku dalam suatu perusahaan merupakan faktor yang utama untuk memungkinkan terlaksananya proses produksi dengan lancar karena tanpa adanya persediaan bahan baku, perusahaan akan dihadapkan pada resiko tidak dapat memenuhi permintaan konsumen. Hal ini bisa terjadi karena tidak selamanya bahan baku yang diperlukan tersedia setiap saat, yang berarti pula bahwa perusahaan akan kehilangan kesempatan memperoleh keuntungan yang seharusnya diperoleh. Oleh sebab itu, setiap perusahaan harus mampu mempertahankan suatu jumlah persediaan yang optimal yang dapat meminimalkan persediaan. 
Menurut Wangsi \& Rawi (2018) menjelaskan bahwa Tingginya permintaan dan kemajuan teknologi menyebabkan terjadinya peningkatan terhadap barang yang dikonsumsi oleh konsumen. Dan seiring berkembangnya zaman pun menjadikan barang yang dikonsumsi ikut turut meningkat persediaannya. Para konsumen yang dihadapkan oleh banyaknya pilihan dari berbagai jenis dan macam barang adalah akibat dari meningkatnya jumlah dan kualitas barang-barang yang dikonsumsi secara terus menerus.

Biaya persediaan terdiri dari biaya pemesanan dan biaya pemeliharaan. Biaya pemesanan merupakan biaya-biaya yang dikeluarkan sehubungan dengan kegiatan pemesanan bahan mentah, misalnya ; biaya-biaya persiapan pemesanan, biaya administrasi, biaya pengiriman pesanan, dan biaya mencocokkan pesanan yang masuk. Biaya pemeliharaan merupakan biaya-biaya yang dikeluarkan sehubungan dengan kegiatan penyimpanan baha baku/mentah yang dibeli, misalnya ; biaya pemeliharaan, biaya asuransi, dan biaya perbaikan kerusakan. Tujuan perusahaan pada umumnya adalah untuk memperoleh laba (profit oriented), meskipun dalam dunia usaha ada juga perusahaan yang nirlaba ( non profit oriented). Laba yang maksimal dapat dipakai dengan pengelolaan usaha yang dilakukan secara efisien dan efektif. Dalam hal ini peran dari manajemen sebagai pengelola dan pengendali seluruh aktivitas perusahaan sangat dibutuhkan. Untuk menjalankan usahanya, suatu perusahaan paling sedikit harus menjalankan tiga kegiatan utama manajemen yang meliputi pemasaran keuangan dan produksi.

Suatu perusahaan pada umumnya melakukan aktivitas megubah input menjadi output melalui proses dan disertai perubahan-perubahan yang tidak menentu dari lingkungan eksternal perusahaan. Kontinuitas jalannya proses produkis dalam perusahaan sangat penting, maka masalah pengendalian persediaan bahan baku merupakan hal yang harus diperhatikan oleh suatu perusahaan, karena pengendalian persediaan bahan baku merupakan salah satu faktor yang berkaitan langusng dengan operasi produks perusahaan, disamping didukung oleh beberapa faktor lainnya kebijakan pengendalian yang sebaiknya dilakukan agar dapat memperoleh hasil yang efektif dan efisien sangat tergantung pada kondisi dan jenis permintaan yang dihadapi. Untuk kelancaran kegiatan proses produksi perusahaan maka dibutuhkan suatu pengendalian persediaan. Yang dimana pengendalian perusahaan adalah suatu kegiatan untuk menentukan tingkat dan komposisi persediaan komponen, bahan baku dan barang jadi sehingga perusahaan dapat melindungi kelancaran produksi dan penjualan serta kebutuhan-kebutuhan pembelanjaan perusahaan yang efektif dan efesien.

PT. Daya Sakti Industri Makassar merupakan perusahaan industri yang kegiatan usahanya 
adalah memproduksi Tegel (keramik). Bahan baku yang digunakan oleh perusahaan ini adalah Pasir, Semen. Bahan baku ini merupakan bahan baku yang sewaktu-waktu ada dalam pasaran. Jadi selama ini perusahaan tidak pernah mengalami kekurangan dalam pembelian bahan baku karena adanya pemasok yang tetap menyediakan bahan pada saat dibutuhkan oleh perusahaan. Untuk membahas masalah ini dibuatlah judul "Penentuan Jumlah Pembelian Bahan Baku Berdasarkan metode Economic Order Quantity pada PT. Daya Sakti Industri Makassar". Kegiatan pengendalaian persediaan yang dilakukan oleh suatu perusahaan dalam pelaksanaannya tidak semudah yang tercantum dalam teori. Dalam melaksanakan penentuan tingkat persediaan yang optimal METODE PENELITIAN Metode Pengumpulan Data

Metode pengumpulan data yang digunakan dalam memperoleh informasi yang dibutuhkan dalam penulisan ini adalah :

1. Dokumentasi

Yaitu metode pengumpulan data yang dilakukan dengan memperlajari dan membaca literatur serta tulisan yang menyangkut teoi-teori yang berhubungan dengan masalah yang dibahas pada penulisan ini.

2. Observasi

Yaitu Metode pengumpulan data yang dilakukan dengan terjun langsung ke perusahaan yang menjadi objek penelitian untuk memperoleh data akurat yang pihak perusahaan harus dapat merencanakan dan menetapkan cara pelaksanaan kegiatan tersebut sehingga tujuan dari penentuan tingkat persediaan dapat mengurangi biaya-biaya produksi.

\section{Tujuan Penelitian}

Tujuan penelitian ini adalah sebagai berikut :

1. Untuk mengetahui besarnya pembelian persediaan bahan baku berdasarkan Economic Order Quantity.

2. Untuk mengetahui pada saat kapan perusahaan harus melakukan pemesanan kembali dengan jumlah pemesanan bahan baku yang tepat dengan biaya yang relatif kecil.

dapat digunakan dalam penulisan ini.

3. Wawancara

Yaitu metode pengumpulan data yang dilakukan dengan bertatap muka langsung dengan responden sehubungan dengan masalah yang diteliti.

\section{Jenis dan Sumber Data}

Jenis data yang digunakan dalam penelitian ini adalah data nominal, sedangkan sumber data adalah sebagai berikut :

1. Data Kualitatif, yaitu jenis data berbentuk non angka yang diperoleh dari perusahaan sehubungan dengan masalah yang diteliti. 
2. Data Kuantitatif, yaitu jenis data yang berbentuk angka peroleh dari perusahaan sehubungan dengan masalah yang diteliti.

Adapun sumber data yang digunakan dalam penelitian ini adalah sebagai berikut :

1. Data Primer, yaitu data yang diperoleh dari wawancara dengan pimpinan dan karyawan yang menjadi sampel penelitian.

2. Data sekunder, yaitu data yang diperoleh dari dokumen atau arsip yang tersedia pada obyek yang diteliti.

\section{Metode Analisis}

Dalam penulisan ini metode yang digunakan adalah metode deskriptif. Hal tersebut dilakukan untuk menggambarkan permasalahan yang dihadapi oleh perusahaan.

Adapun alat analisis yang digunakan adalah :

1. Metode Kuantitas Pesanan Ekonomis (Economical Order Quantity)

Metode ini merupakan alat yang digunakan untuk menentukan besarnya pesanan yang dapat meminimumkan biaya pemesanan dan biaya penimpanan bahan baku.

Formula yang digunakan, yaitu :

$$
E O Q=\sqrt{\frac{2 x R x S}{C}}
$$

Keterangan :

$$
\begin{array}{ll}
\text { EOQ } \quad \text { Kuantitas } \\
& \text { pesanan } \\
& \text { yang } \\
& \text { ekonomis } \\
& (\text { Economic }
\end{array}
$$

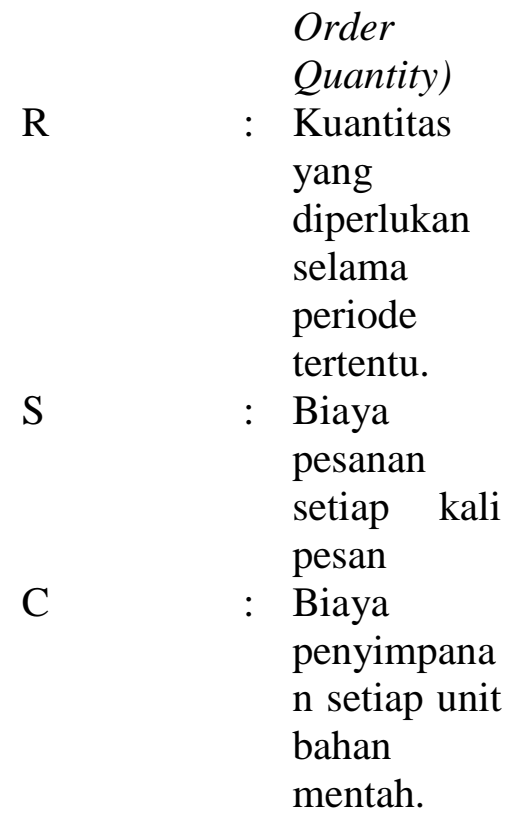

2. Metode Titik Pemesanan Kembali (Reorder Point)

Metode Titik Pemesanan Kembali (Reorder Point) adalah saat dimana harus dilakukan pemesanan kembali bahan mentah yang diperlukan.

Formula yang digunakan :

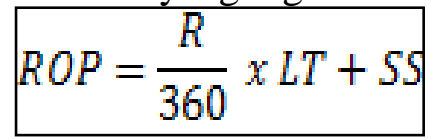

Keterangan :

$\begin{array}{ll}\text { ROP } \quad: ~ & \text { Titik } \\ & \text { pemesanan } \\ & \text { kembali } \\ & \text { (reorder } \\ & \text { point) } \\ & \text { R } \quad \text { Jumlah bahan } \\ & \text { baku yang } \\ & \text { dibutuhkan } \\ & \text { pertahun } \\ & \text { Tengangan } \\ & \text { waktu yang } \\ & \text { diperlukan }\end{array}$


3. Persediaan pengaman (safett

untuk

memesan

suatu barang

(lead time)

SS : Persediaan

minimum

(safety stock)

stock/SS)

\section{HASIL PENELITIAN DAN}

PEMBAHASAN

Perkembangan Produksi dan Penjualan Genteng pada PT. Daya Sakti Industri Makassar

Pemasaran suatu produk dapat dikatakan berhasil, bila produk yang ditawarkan dapat diterima konsumen atau pemakai akhir tepat pada waktunya. Dan dengan tingkat harga yang dapat dijangkau oleh konsumen, sedangkan di pihak perusahaan dapat memperoleh suatu keuntungan yang memadai. Selain itu kriteia lain adalah produk itu dapat dengan mudah sampai ke tangan konsumen dengan suatu pengeluaran yang tidak terlalu besar serta produk tersebut merupakan produk yang di butuhkan oleh konsumen.Sebagaiman kita ketahui bahwa pemasaran adalah sebagai bagian dari kegiatan perusahaan. Bagaimanapun baiknya kegiatan dalam perusahaan tetapi tidak mampu memasarkan hasil produknya, maka kelangsungan hidup perusahaan dapat terganggu.

$\begin{array}{lcc}\text { Merupakan } & \text { persediaan } & \text { yang } \\ \text { disimpan perusahaan } & \mathrm{d} \\ \text { menjaga } & \text { kelancaran } & \mathrm{p} \text { 1 } \\ \text { produksi } & \text { bila } & \text { te }{ }_{\text {1jau }} \\ \text { keterlambatan } & \text { tibanya pesanan } \\ \text { dan untuk } & \text { menanggulangi } \\ \text { kemungkinan } & & \text { kehabisan } \\ \text { persediaan. } & \end{array}$

Seperti diketahui sebelumnya pada waktu lalu kegiatan perusahaan lebih diarahkan pada kegiatan produksi dengan kata lain perusahaan masih berorientasi pada bidang produksi daripada berorientasi pada pemasaran. Hal ini dapat dimengerti karena hampir seluruh barang-barang yang diproduksi dapat dijual habis aatau kekauaran pasar ada di tangan penjual (seller market).

Dengan memperhatikan hasil-hasil yang telah dicapai oleh pihak perusahaan PT. Daya Sakti Industri Makassar saat ini, maka kita dapat menarik kesimpulan bahwa perusahaan telah mengalami perkembangan baik produksi maupun kualitas produksi. Untuk jelasnya penulis akan menyajikan perkembangan penjualan perusahaan pada tahun 2012 khusus untuk produk genteng. Dengan data ini untuk melihat sampai sejauh mana kapasitas volume penjualan genteng yang telah dicapai oleh perusahaan selama ini dan juga sebagai bahan informasi bagi perusahaan untuk produksi pada tahun berikutnya.

Tabel. 2. Perkembangan Produksi dan Penjualan Genteng Pada PT. Daya Sakti Industri Makassar, Tahun 2012 s.d. 2016.

Tahun Produksi (Unit) Permintaan berdasarkan 


$\begin{array}{lcc} & \text { Pesanan (Unit) } \\ 2012 & 504.000 & 450.000 \\ 2013 & 519.000 & 470.000 \\ 2014 & 575.000 & 500.000 \\ 2015 & 630.000 & 625.000 \\ 2016 & 746.000 & 695.100\end{array}$

Sumber : PT. Daya Sakti Industri Makassar, Tahun 2017

Adapun biaya pesanan dan biaya penyimpanan dapat kita lihat pada tabel berikut :

Tabel. 3. Biaya Pesanan dan Biaya Penyimpanan PT. Daya Sakti Industri

$\begin{array}{ccc}\text { Tahun } & \text { Biaya pesanan }(\mathrm{Rp}) & \text { Biaya Persediaan }(\mathrm{Rp}) \\ 2012 & 5.625 .000 .000 & 6.300 .000 .000 \\ 2013 & 5.875 .000 .000 & 6.487 .000 .000 \\ 2014 & 6.250 .000 .000 & 7.187 .500 .000 \\ 2015 & 7.812 .500 .000 & 7.875 .000 .000 \\ 2016 & 8.688 .750 .000 & 9.325 .000 .000\end{array}$

Sumber : PT. Daya Sakti Industri Makassar, Tahun 2016

Dengan melihat tabel 2 di atas, terlihat bahwa jumlah produksi perusahaan dalam satu tahun selama tahun 2012 adalah 504.000 unit. Total produksi dalam satu tahun 504.000 dibagi 12 bulan sehingga produksi rata-rata sebulan sebanyak 42.000 unit. Sedangkan permintaan rata-rata setahun adalah 450.000/12 $=37.500$ unit. Demikian pula pada tahun 2013, 2014, 2015, dan 2016. Pada tabel 3 nampak bahwa biaya pesan adalah Rp. 5.625.000.000 pada 2013 dan meningkat menjadi Rp. 5.875.000.000 pada tahun 2014 . Demikian pula pada tahun 2015 s.d tahun 2016 biaya pesanan terus mengalami peningkatan yaitu $\mathrm{Rp}$. 8.688.750.000.

\section{Untuk Tahun 2012}

a. Jumlah produksi dalam satu tahun adalah 504.000 unit, berarti jumlah produksi dalam satu hari sebesar 1.400 unit.
Economic Order Quantity (EOQ)

Model Economic Order Quantity (EOQ) dasar menganggap bahwa kuantitas yang dipesan dan diterima seluruhnya pada saat yang sama, dalam jumlah tunggal Q. Berbagai produk yang dibeli dan diproduksi sendiri perusahaan tidak memenuhi pada saat seketika dan sebagian secara bertahap.

Berdasarkan data produksi dan permintaan genteng yang terdapat pada tabel 2 serta biaya pesanan dan permintaan produk (tabel 3) pada PT. Daya Sakti Industri Makassar tersebut maka dapat dihitung Economic Order Quantity sebagai berikut :

$$
\mathrm{D}=1.400
$$

unit/hari

$$
\mathrm{D}=1.400
$$




$$
\mathrm{D}=504.000
$$

unit/tahun

b. Jumlah permintaan dalam satu tahun adalah sebesar 450.000 unit, berarti jumlah permintaan dalam satu hari adalah :

c. Tingkat produksi per hari sebesar 1.400 unit, sedangkan tingkat permintaan adalah sebesar 1.250 unit. Hal ini merupakan kebijaksanaan perusahaan untuk memproduksi lebih 5 unit per hari untuk menjadi cadangan sebagai pengganti apabila ada barang yang rusak.

d. Biaya penyimpanan adalah 12 $\%$ dari harga rata-rata genteng per unit, yaitu sebesar $12 \% \mathrm{x}$ Rp. $12.500=$ Rp. 1.500

e. Biaya pesanan adalah sebesar Rp. 5.625.000.000 dibagi 12 bulan, dibagi 30 hari $=\mathrm{Rp}$. 15.625.000 per setiap kali pesan.

Dari data-data tersebut di atas dapat dihitung Economic Order Quantity (EOQ) sebagai berikut :

$$
\begin{array}{lll} 
& \mathrm{D}= & 504.000 \\
\text { unit } & & \\
& \mathrm{S}= & 15.625 .000 \\
\text { per pesanan } & \\
\mathrm{H}= & \text { Rp. } 1.500
\end{array}
$$

Kuantitas pesanan tidak diterima dalam jumlah besar, tetapi dalam

\begin{tabular}{|c|c|c|}
\hline \multirow{2}{*}{\multicolumn{2}{|c|}{$\mathrm{d}=$}} & 450.000 unit \\
\hline & & 360 hari \\
\hline & $=$ & 1.250 unit \\
\hline
\end{tabular}
kuantitas-kuantitas yang lebih kecil sejalan dengan kemajuan produksi. Produk-produk yang dibeli atau diproduksi sendiri mempunyai

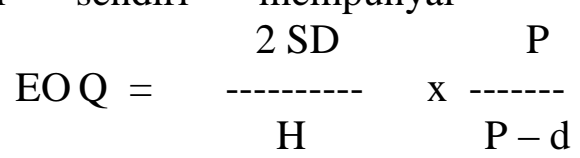

tingkat produksi (P) yang relatif lebih besar daripada tingkat permintaan (d).

Anggapan-anggapan dan istilah model ini yang berbeda dari model dasar dapat diperinci sebagai berikut

1. Kuantitas tidak dipenuhi semuanya pada saat yang sama tetapi tersedia dalam kuantitas-kuantitas lebih kecil pada tingkat produksi atau pemenuhan konstan $(\mathrm{P})$.

2. Tingkat permintaan (d) besarnya relatif terhadap tingkat produksi

3. Selama produksi dilakukan (tp), tingkat pemenuhan persediaan bahan baku adalah sama dengan tingkat produksi dikurangi tingkat permintaan (p-d).

4. Selama Q unit produksi, besarnya tingkat persediaan maksimum kurang dari Q karena penggunaan selama pemenuhan.

Rumusan Economic Order Quantity (EOQ), Handoko (2003:75) sebagai berikut : 


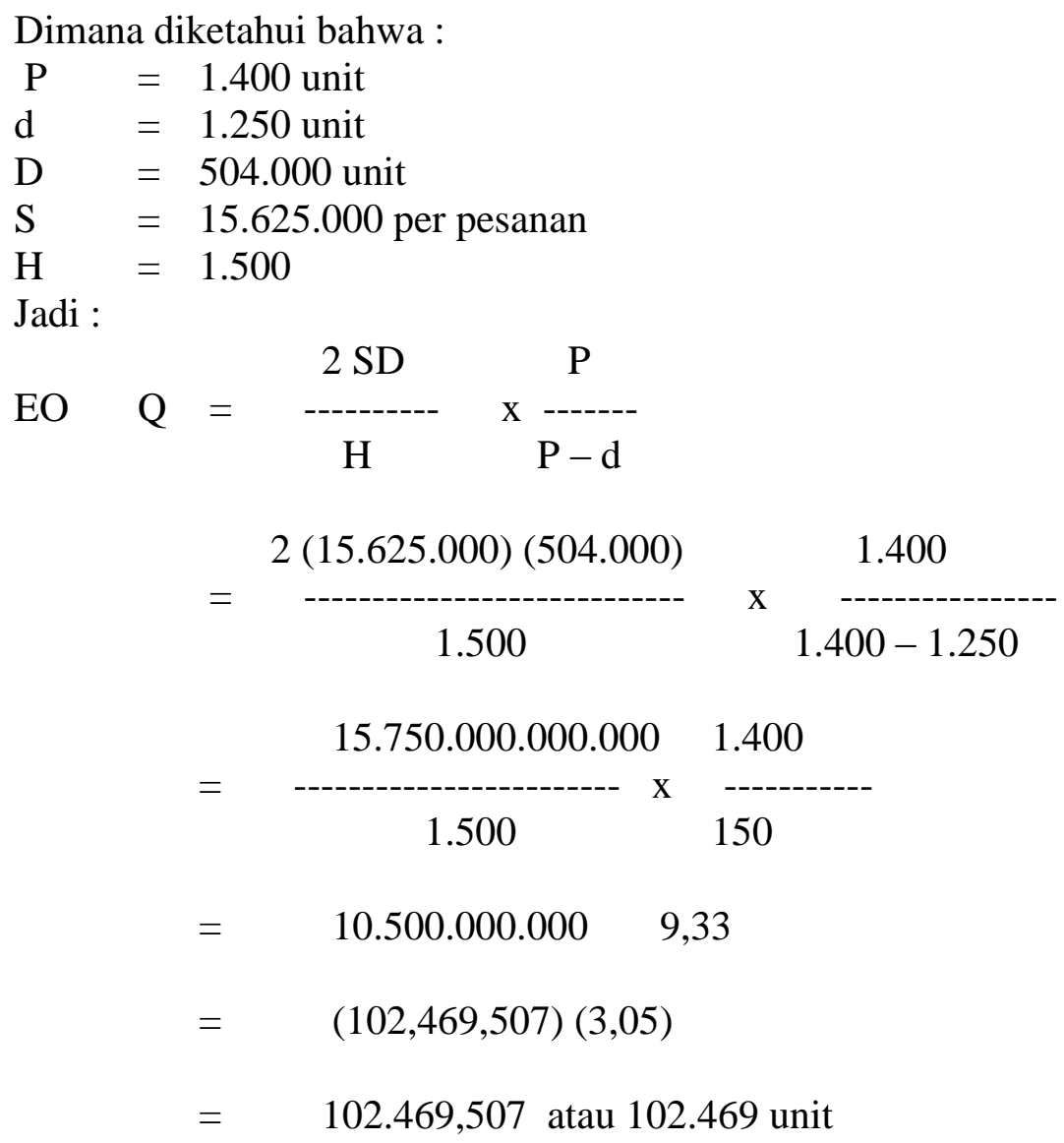

Dari data di atas dapat diketahui banyaknya persediaan dengan menggunakan metode Economic Order Quantity (EOQ) adalah 102.469,507 dibulatkan menjadi 102.469 unit.Selanjutnya untuk

$$
\begin{aligned}
& \begin{array}{ccc}
\mathrm{D} & \mathrm{Q} \\
\mathrm{TC} & \mathrm{DC}+--- & \mathrm{S}+--\mathrm{H} \\
& & 2
\end{array} \\
& 504.000 \quad 102.469 \\
& \mathrm{TC}=450.000+\frac{--------}{102.469}(15.625 .000)+------(1.500) \\
& =450.000+(4,918)(15.625 .000)+(51.234)(1.500) \\
& =450.000+76.843 .750+76.851 .000 \\
& =\text { Rp. 154.144.750,- }
\end{aligned}
$$

Dari hasil perhitungan di atas bahan baku sebesar Rp. diperoleh hasil total biaya persediaan 154.144.750,- 
2. Untuk Tahun 2013

a. Jumlah produksi dalam satu tahun adalah 519.000 unit, berarti jumlah produksi dalam satu hari sebesar $1.441,6$ unit $=1.441$ unit

$\mathrm{D} \quad=1.441$ unit/hari

$\mathrm{D} \quad=1.441(360)$

c. Biaya penyimpanan adalah

$$
\begin{aligned}
D & =\frac{470.000 \text { unit }}{-------} \\
& =1.360 \text { hari }
\end{aligned}
$$

$12 \%$ dari harga rata-rata genteng per unit, yaitu sebesar $12 \%$ x Rp. $12.500=$ Rp. 1.500

d. Biaya pesanan adalah sebesar Rp. 16.319.444 per setiap kali pesan/.

$$
\text { EOQ }=\begin{array}{ccc}
\text { 2SD } & & \text { P } \\
\text { H } & & \text { P - d }
\end{array}
$$

Dimana diketahui bahwa :

$$
\begin{array}{ll}
\mathrm{P} & =1.441 \mathrm{unit} / \mathrm{hari} \\
\mathrm{d} & =1.305 \mathrm{unit} / \mathrm{hari} \\
\mathrm{D} & =519.000 \mathrm{unit} \\
\mathrm{S} & =16.319 .444 \text { per pesanan } \\
\mathrm{H} & =1.500
\end{array}
$$

Jadi :

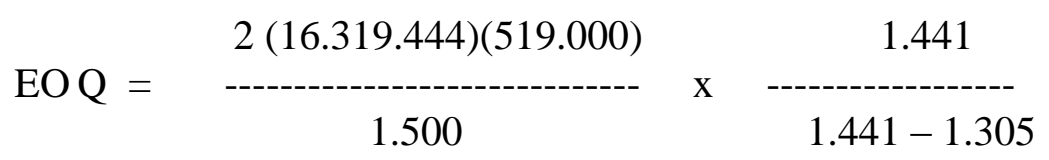

Dari data-data tersebut di atas dapat dihitung Economic Order Quantity (EOQ) sebagai berikut : tahun adalah sebesar 470.000 unit, berarti jumlah permintaan dalam satu hari adalah : 


$$
\begin{aligned}
& =\quad(106.268,787(3,25) \\
& =\quad 345.373,557 \text { atau } 345.374 \text { unit }
\end{aligned}
$$

$\begin{array}{lrrl}\text { Dari data di } & \text { atas dapat } & \text { (EOQ) adalah } 345.373,557 \\ \text { diketahui } & \text { banyaknya } & \text { dibulatkan menjadi 345.374 } \\ \text { persediaan } & \text { dengan } & \text { unit. } \\ \text { menggunakan } & \text { metode } & \text { Total biaya persediaan : }\end{array}$

Economic Order Quantity

$$
\begin{aligned}
& \text { D Q } \\
& \mathrm{TC}=\mathrm{DC}+\underset{\mathrm{Q}}{-----} \mathrm{S}+\underset{2}{---} \mathrm{H} \\
& \mathrm{TC}=470.000+\frac{519.000}{345.374}(16.319 .444)+\text { - } 4 \text { (1.500) } \\
& =470.000+(1,502)(16.319 .444)+(172.687)(1.500) \\
& =470.000+24.511 .804,888+259.030 .500 \\
& =\text { Rp. 284.012.304,888 } \\
& =\text { Rp. 284.012.305 }
\end{aligned}
$$

Dari hasil perhitungan di atas diperoleh hasil total biaya persediaan bahan baku sebesar Rp. 284.012.305,-

permintaan dalam satu hari adalah :

$$
\begin{aligned}
\mathrm{d} \quad & \begin{array}{c}
500.000 \text { unit } \\
\end{array} \\
= & 1.360 \text { hari }
\end{aligned}
$$

a. Jumlah produksi dalam satu tahun adalah 575.000 unit, berarti jumlah produksi dalam satu hari sebesar 1.597 unit.

$$
\begin{aligned}
\text { unit/hari } & \mathrm{D}=1.597 \\
\mathrm{D} & =1.597 \\
\mathrm{D} & =575.000
\end{aligned}
$$

unit/tahun

b. Jumlah permintaan dalam satu tahun adalah sebesar 500.000 unit, berarti jumlah Tingkat produksi per hari sebesar 1.597 unit/hari, sedangkan tingkat permintaan adalah sebesar 1.388 unit/hari.

c. Biaya penyimpanan adalah $12 \%$ dari harga rata-rata genteng per unit, yaitu sebesar $12 \%$ x Rp. $12.500=$ Rp. 1.500

d. Biaya pesanan adalah sebesar Rp. 17.361.111 setiap kali pesan/.

Dari data-data tersebut di atas dapat dihitung Economic Order $2 \mathrm{SD} \quad \mathrm{P}$

Quantity (EOQ) sebagai berikut : 


$$
\mathrm{EOQ}=\quad \begin{array}{cr}
------- \\
\mathrm{H}
\end{array} \quad \mathrm{P}-\overline{\mathrm{P}-\mathrm{d}}
$$

Dimana diketahui bahwa :

$$
\begin{array}{ll}
\mathrm{P} & =1.597 \text { unit } \\
\mathrm{d} & =1.388 \text { unit } \\
\mathrm{D} & =575.000 \text { unit } \\
\mathrm{S} & =17.361 .111 \text { per pesanan } \\
\mathrm{H} & =1.500
\end{array}
$$

Jadi :

$$
\begin{aligned}
& \text { EOQ }=\begin{array}{c}
2 \text { SD } \\
------- \\
H
\end{array} \quad \text { P } \quad \text { P - }
\end{aligned}
$$

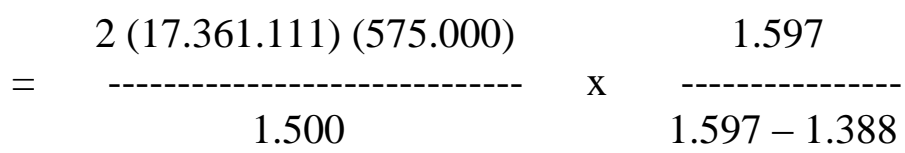

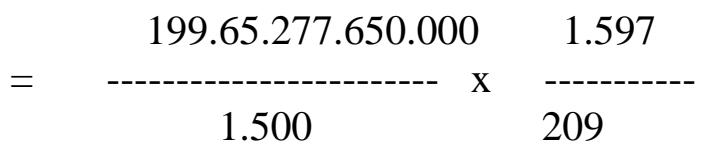

$$
\begin{aligned}
& =\quad 13.310 .185 .100 \quad 7,64 \\
& =\quad(115.369,775)(2,76) \\
& =\quad 318.420,579 \text { atau } 318.421 \text { unit }
\end{aligned}
$$

Dari data di atas dapat diketahui Order Quantity (EOQ) adalah banyaknya persediaan dengan 318.420,579 dibulatkan menjadi menggunakan metode Economic 318.421 unit.

Total biaya persediaan :

$$
\begin{aligned}
& \mathrm{TC} \quad=\mathrm{DC}+\underset{\mathrm{Q}}{\mathrm{D}} \stackrel{\mathrm{Q}}{\mathrm{----}} \mathrm{S}+\frac{\mathrm{-}}{\mathrm{H}} \mathrm{H} \\
& \text { TC } \\
& =500.000+\frac{575.000}{318.421}(17.361 .111)+-------(1.500) \\
& =500.000+(1,805)(17.361 .111)+(159.210)(1.500) \\
& =500.000+31.336 .805,355+238.815 .000 \\
& =\text { Rp. } 270.651 .805,355 \\
& =\text { Rp. } 270.651 .805
\end{aligned}
$$


Dari hasil perhitungan di atas diperoleh hasil total biaya persediaan bahan baku sebesar Rp. 270.651.805,-

\section{Untuk Tahun 2015}

a. Jumlah produksi dalam satu tahun adalah 630.000 unit, berarti jumlah produksi dalam satu hari sebesar 1.750 unit.

D

$$
\begin{aligned}
= & 1.750 \text { unit/hari } \\
\mathrm{d}= & 625.000 \text { unit } \\
= & 360 \mathrm{hari} \\
= & 1.736 \text { unit/hari }
\end{aligned}
$$

Tingkat produksi per hari sebesar 1.750 unit/hari, sedangkan tingkat permintaan adalah sebesar 1.736 unit/hari.

c. Biaya penyimpanan adalah 12 $\%$ dari harga rata-rata genteng per unit, yaitu sebesar $12 \% \mathrm{x}$ Rp. $12.500=$ Rp. 1.500

$$
\mathrm{EOQ}=\begin{array}{ccc}
\text { 2SD } & & \mathrm{P} \\
\mathrm{H} & & \mathrm{P}-\mathrm{d}
\end{array}
$$

Dimana diketahui bahwa :

$$
\begin{aligned}
\mathrm{P} & =1.750 \text { unit } \\
\mathrm{d} & =1.736 \text { unit } \\
\mathrm{D} & =630.000 \text { unit } \\
\mathrm{S} & =21.701 .389 \text { per pesanan } \\
\mathrm{H} & =1.500
\end{aligned}
$$

Jadi :
$\mathrm{D}=1.750(360)$

$\mathrm{D}=630.000$

unit/tahun

b. Jumlah permintaan dalam satu tahun adalah sebesar 625.000 unit, berarti jumlah permintaan dalam satu hari adalah : d. Biaya pesanan adalah sebesar Rp. 21.701.389 setiap kali pesan.

Dari data-data tersebut di atas dapat dihitung Economic Order Quantity (EOQ) sebagai berikut :

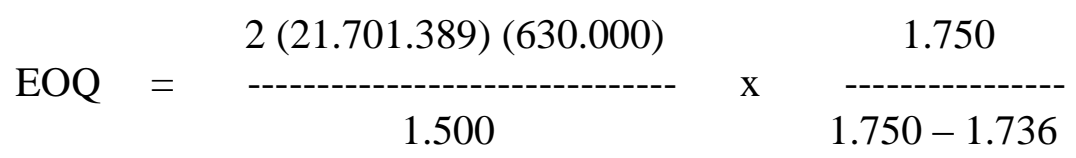




\begin{tabular}{|c|c|c|c|}
\hline \multicolumn{2}{|c|}{27.343 .750 .140 .000} & $\mathrm{X}$ & 1.750 \\
\hline & 1.500 & & 14 \\
\hline & 18.229 .166 .760 & $(12$ & 5) \\
\hline & $(135.015,431)(11$ & ,18) & \\
\hline & $1.509 .472,518$ ata & 1 & 99.473 unit \\
\hline
\end{tabular}

Dari data di atas dapat diketahui 1.509.472,518 dibulatkan menjadi banyaknya persediaan dengan 1.509.473 unit. menggunakan metode Economic

Order Quantity (EOQ) adalah

Total biaya persediaan :

$$
\begin{aligned}
& \mathrm{TC} \quad=\mathrm{DC}+\stackrel{\mathrm{D}}{-----} \mathrm{S}+\frac{\mathrm{Q}}{\mathrm{Q}} \quad \mathrm{H} \\
& \text { TC } \quad \text { = } 625.000+\frac{630.000}{1.509 .473}(21.701 .389)+-\frac{1.509 .473}{--0-}(1.500) \\
& =625.000+(0,417)(21.701 .389)+(754.736)(1.500) \\
& =625.000+9.049 .479,213+1.132 .104 .000 \\
& =\text { Rp. 1.141.778.479,21 } \\
& =\text { Rp. 1.141.778.479 }
\end{aligned}
$$

Dari hasil perhitungan di atas diperoleh hasil total biaya persediaan

5. Untuk Tahun 2016

a. Jumlah produksi dalam satu tahun adalah 746.000 unit, berarti jumlah produksi dalam satu hari sebesar 2.072 unit.

unit/hari

$$
\mathrm{D}=2.072
$$

$$
\mathrm{D}=2.072
$$

(360)

$$
\mathrm{D}=746.000
$$

unit/tahun

b. Jumlah permintaan dalam satu tahun adalah sebesar 695.000 unit, berarti jumlah permintaan dalam satu hari adalah : bahan baku sebesar Rp.1.141.778.479,695.000 unit

$$
\begin{aligned}
\mathrm{d} \quad & =-160 \text { hari } \\
& =1.930 \text { unit }
\end{aligned}
$$

Tingkat produksi per hari sebesar 2.072 unit/hari, sedangkan tingkat permintaan adalah sebesar 1.930 unit/hari.

c. Biaya penyimpanan adalah 12 $\%$ dari harga rata-rata genteng per unit, yaitu sebesar $12 \% \mathrm{x}$ Rp. $12.500=$ Rp. 1.500 . 
d. Biaya pesanan adalah sebesar Rp. 24.135.416 setiap kali pesan/.

Dari data-data tersebut di atas dapat dihitung

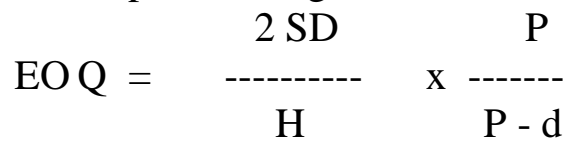

Dimana diketahui bahwa :

$$
\begin{array}{ll}
\mathrm{P} & =2.072 \text { unit } \\
\mathrm{d} & =1.930 \text { unit } \\
\mathrm{D} & =746.000 \text { unit } \\
\mathrm{S} & =24.135 .416 \text { per pesanan } \\
\mathrm{H} & =1.500
\end{array}
$$

Jadi :

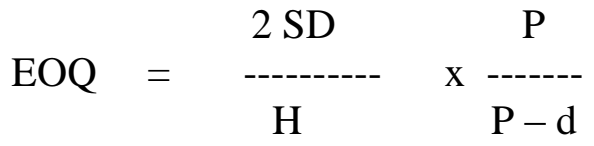

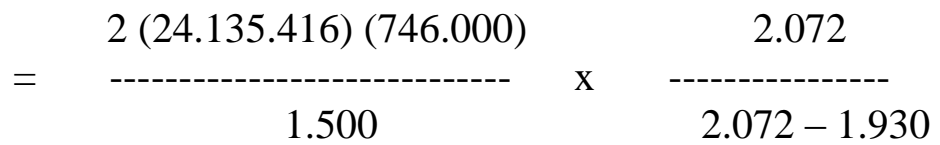

$$
\begin{aligned}
& \begin{array}{ccc}
\text { 72.020.081.344.000 } & & 2.072 \\
---------- \\
\hline 1500 & x & 142
\end{array} \\
& =\quad 48.013 .387 .563 \quad 14,59 \\
& =(219.119,573)(3,81) \\
& =834.845,573 \text { atau } 834.846 \text { unit }
\end{aligned}
$$

Economic Order Quantity (EOQ) sebagai berikut :

Dari data di atas dapat diketahui banyaknya persediaan dengan 834.845,573 dibulatkan menjadi menggunakan metode Economic Order Quantity (EOQ) adalah

Total biaya persediaan :

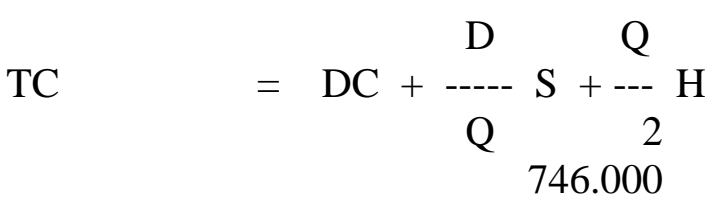


TC

$$
\begin{aligned}
= & 695.000+\frac{834.846}{----(24.135 .416)}+-(1.500) \\
= & 695.000+(0,893)(24.135 .416)+(417.423)(1.500) \\
= & 695.000+21.552 .926,488+626.134 .500 \\
= & \text { Rp. } 648.382 .426,488 \\
= & \text { Rp. 648.382.426 }
\end{aligned}
$$

Dari hasil perhitungan di atas diperoleh hasil total biaya persediaan bahan baku sebesar Rp.

Dari hasil perhitungan di atas, dapat 648.382.426,-

kita lihat dalam bentuk tabel sebagai berikut :

\section{Tabel. 4. Total Biaya Persediaan Bahan Baku Menurut EOQ Tahun 2012 s.d.}

Tahun 2016

$\begin{array}{ccc}\text { Tahun } & \begin{array}{c}\text { Kuantitas Pesanan (EOQ) } \\ \text { Dalam unit }\end{array} & \begin{array}{c}\text { Total Biaya Persediaan } \\ (\mathrm{Rp})\end{array} \\ 2012 & 102.469 & 154.144 .750 \\ 2013 & 345.374 & 284.012 .305 \\ 2014 & 318.421 & 270.651 .805 \\ 2015 & 1.569 .473 & 1.141 .778 .479 \\ 2016 & 834.846 & 648.382 .426\end{array}$

Sumber : Data diolah, 2017

Dari tabel tersebut nampak bahwa total biaya persediaan jika menggunakan EOQ lebih hemat jika dibandingkan dengan total biaya persediaan dari perusahaan (tabel 3). Demikian pula dengan kuantitas pesanan. Dengan demikian

\section{KESIMPULAN DAN SARAN}

\section{Kesimpulan}

Berdasarkan hasil analisis dalam pembahasan, maka penulis dapat menarik kesimpulan sebagai berikut :

1. Untuk setiap perusahaan perlu diadakan pengendalian terhadap persediaan, baik terhadap bahan baku, barang jadi, dan barang setengah jadi. Dengan adanya pengendalian persediaan, maka perusahaan akan terhindar dari resiko kerugian. Bahan baku merupakan bahan dasar yang sangat menentukan bagi suatu produk, oleh kerena itu perlu perusahaan belum hemat biaya dalam mengendalikan persediaan bahan bakunya, berarti sesuai dengan hipotesis yang telah diajukan, dalam arti hipotesis diterima.

dikendalikan dengan baik agar tidak menimbulkan kerugian perusahaan.

2. Setelah melihat hasil perhitungan analisis yang kami pakai yaitu Economic Order Quantity (EOQ) maka dapat dilihat bahwa PT. Daya Sakti Industri Makassar selama ini belum optinal dalam tingkat produksi yang ekonomis karena dalam melaksanakan produksinya tidak memperhatikan Economic Order Quantity, sehingga biaya persediaan menjadi tinggi. 


\section{Saran-Saran}

Adapun saran-saran dalam penulisan ini adalah :

1. Hendaknya perusahaan PT. Daya Sakti Industri Makassar dalam merencanakan jumlah penjualan yang akan datang agar menggunakan metode least square dengan trend garis lurus mengingat kebutuhan akan produksi genteng terus meningkat.

2. Agar perusahaan PT. Daya Sakti Industri Makassar dalam menentukan tingkat produksi yang ekonomis menggunakan peralatan analisis Economic Order Quantity.

\section{DAFTAR PUSTAKA}

Anoraga, Pandji, 2000. "Manajemen Bisnis”. Jakarta : Rineka Cipta.

Ginting, Umumtha, S.M, Sibarani, 1995. "Manajemen Produksi”. Bandung : Pusat Pengembangan Politeknik.

Hading, H.A, 1999. "Manajemen Produksi”. Jakarta : Balai Aksara.

Ikatan Akuntansi Indonesia, 2007. "Standar Akuntansi Keuangan”. Jakarta : Salemba Empat.

Matz, Adoplh dkk. 1998. "Akuntansi Biaya”. Jakarta : Erlangga.

Mulyadi, 1999. "Akuntansi Biaya". Yogykarta : Aditya Media.

Rangkuti, Freddy, 2000. "Manajemen Persediaan". Jakarta : PT. Raja Grafindo Persada.
Simamora, Henry, 1999. "Akuntansi Manajemen”. Jakarta : Salemba Empat.

Stoner, James A.E. dkk. 1996. “Manajemen”. Jakarta : PT. Prenhallindo.

Syamsuddin, Lukman, 1995. "Manajemen Keuangan Perusahaan”. Jakarta. PT. Raja Grafindo Persada.

Taylor III, Bernrd W, 2001. "Sains Manajemen”. Jakarta : Salemba Empat.

Usry, Milto F, Lawrence H Hammer, 1996. "Akuntansi Biaya”. Jakarta : Erlangga

Sutrisno, 2000. "Manajemen Keuangan”. Edisi Pertama, Yogyakarta : Ekonisia.

Wangsi, M. M., \& Rawi, R. D. P. (2018). Perlindungan Konsumen Dalam Pelabelan Produk Menurut Ekonomi Islam. Sentralisasi, 7(1), 1-9. 